\title{
Enhanced Catalytic Activity of Supported Gold Catalysts for Oxidation of Noxious Environmental Pollutant CO
}

\author{
Pranjal Saikia, ${ }^{1}$ Abu Taleb Miah, ${ }^{1}$ Banajit Malakar, ${ }^{1}$ and Ankur Bordoloi ${ }^{2}$ \\ ${ }^{1}$ Department of Applied Sciences (Chemical Science Division), GUIST, Gauhati University, Guwahati, Assam 781014, India \\ ${ }^{2}$ Nano Catalysis, Catalytic Conversion and Process Division, CSIR-Indian Institute of Petroleum, Mohkampur, \\ Dehradun 248005, India \\ Correspondence should be addressed to Pranjal Saikia; psjorhat@gmail.com
}

Received 28 May 2015; Accepted 13 August 2015

Academic Editor: Jose L. Endrino

Copyright (C) 2015 Pranjal Saikia et al. This is an open access article distributed under the Creative Commons Attribution License, which permits unrestricted use, distribution, and reproduction in any medium, provided the original work is properly cited.

\begin{abstract}
Noble metal nanomaterials have attracted mounting research attention for applications in diverse fields of catalysis, biology, and nanotechnology. In the present study, we have undertaken a detailed investigation on synthesis, characterization, and catalytic activity studies for $\mathrm{CO}$ oxidation by nanogold catalysts supported over $\mathrm{CeO}_{2}$ and $\mathrm{CeO}_{2}-\mathrm{ZrO}_{2}(1: 1$ mole ratio). The support systems were prepared by modified, simple precipitation technique and the Au supported samples were synthesized using depositionprecipitation with urea method. The physicochemical characterization was performed by XRD, ICP-AES, BET surface area, FT-IR, UV-Vis DRS, Raman Spectroscopy, TEM, and XPS techniques. $\mathrm{Au} / \mathrm{CeO}_{2}$ catalyst showed more than $80 \% \mathrm{CO}$ conversions at $30^{\circ} \mathrm{C}$, whereas $\mathrm{Au} / \mathrm{CeO}_{2}-\mathrm{ZrO}_{2}$ exhibited $\sim 100 \% \mathrm{CO}$ conversion at that temperature. The catalytic performance of Au catalysts is highly dependent on the nature of the support.
\end{abstract}

\section{Introduction}

The curiosity in using gold as a catalyst component has increased during the last few years after the revolutionary work on Au catalysts by Haruta, reporting surprisingly high $\mathrm{CO}$ oxidation activity of gold nanoparticles [1-10]. When it is suitably employed, supported gold is capable of catalyzing a wide variety of reactions. Nevertheless, much skill is needed to achieve this. In recent times, the catalytic applications of gold have been explored extensively in several processes such as chemical processing, hydrotreatment, and purification of hydrogen for fuel cell applications and in reactions of environmental importance such as catalytic treatment of vehicle exhausts and removal of volatile organic compounds [3-6]. There is no denial to the fact that strict automotive regulations all over the world have necessitated the development of new catalysts to reduce automotive exhaust gases such as $\mathrm{CO}, \mathrm{NO}_{x}$, and hydrocarbons. Finding an efficient catalyst working at mild, environmentally benign conditions therefore remains a challenge.

Ceria $\left(\mathrm{CeO}_{2}\right)$ has been regarded as one of the most important components in many catalytic systems due to its remarkable redox properties and striking oxygen storage capacity $[3,7]$. It has been of wide interest for decades because of its important applications including three way catalysts for automotive emission control [7-9]. Under various redox conditions, the oxidation state of the cation may vary between +3 and +4 . Its distinct defect chemistry and the ability to exchange lattice oxygen with the gas phase result in an oxide with unique catalytic properties [7-10]. Literature reveals that ceria and its mixed oxides are very good catalysts for $\mathrm{CO}$ oxidation reaction at high temperatures (above $350^{\circ} \mathrm{C}$ ) [7-13]. In this view, there has been a tremendous growth in research for $\mathrm{CO}$ oxidation using Au catalysts supported over ceria that can be used for low temperature applications like abatement of environmental pollutants (e.g., $\mathrm{CO}, \mathrm{NO}_{x}$, and VOCs) and synthesis of chemicals via selective oxidation/hydrogenation [10-13]. Many active gold catalysts are composed of gold nanoparticles (Au-NPs) and a powder support that usually have simple metal-support interfaces. However, one problem generally encountered with these catalysts is the relatively weak metal-support interaction, which may lead to the sintering of gold nanoparticles at elevated temperatures. Therefore, several strategies have been implemented to construct gold 
catalysts with diversified local structures and better catalytic performance [14-16].

It is noteworthy that $\mathrm{CeO}_{2}$ itself has not been recognized as an excellent catalyst for low temperature CO oxidation [3]. However, keeping in consideration the ability of both ceria and $\mathrm{Au}$ in catalyzing $\mathrm{CO}$ oxidation reaction alone, there is always a good possibility of designing promising catalyst for the said reaction when ceria and Au are combined in effective ways. In view of this huge possibility, there is still need to explore systems having Au over ceria or ceria-based materials. Reports could be found for such systems in literature showing very good activity for the said reaction $[4,17,18]$. However, the methods of preparation of most the catalysts are based mainly on sol-gel technique. Here, we have tried to apply simpler synthesis method using coprecipitation technique without using any specific arrangement. Against this background, we have carried out a systematic investigation on synthesis of gold nanocatalysts supported over ceria and one of its most prominent mixed oxides, ceria-zirconia, which is also better known for superior thermal stability and easy reducibility [7]. The support systems were prepared by modified, simple precipitation technique and the Au supported samples were synthesised using deposition-precipitation with urea method. The physicochemical characterization was performed by XRD, ICP-AES, BET surface area, FT-IR spectroscopy, UV-Vis DRS, Raman Spectroscopy, TEM, and XPS techniques. Finally, the catalytic performance of the synthesised catalysts was evaluated for $\mathrm{CO}$ oxidation reaction.

\section{Experimental}

2.1. Materials. All the chemicals used in this study were of analytical grade and we used them without further purification. In all experiments, double distilled water was used.

2.2. Synthesis of $\mathrm{CeO}_{2}(\mathrm{C})$ and $\mathrm{CeO}_{2}-\mathrm{ZrO}_{2}$ (CZ). Both ceria and ceria-zirconia (1:1 mole ratio based on oxides) solid solutions were prepared by adopting a coprecipitation method using ammonium cerium (IV) nitrate (Himedia) and zirconium oxychloride (Himedia), respectively. For preparation of ceria, required amount of the precursor was dissolved in double distilled water, whereas for the case of the mixed oxide required amounts of precursors were dissolved separately in double distilled water under mild stirring conditions and mixed together. Upon complete mixing, excess ammonium hydroxide was added dropwise until the precipitation was complete $(\mathrm{pH}=\sim 8.5)$. The resulting slurry was filtered off and thoroughly washed with distilled water until it became free from anion impurities. The accumulated oxide and the mixed oxide pastes were carefully placed and covered in a clean ceramic crucible and allowed to dry overnight in a hood. The oxide and mixed oxide samples were then oven-dried at $120^{\circ} \mathrm{C}$ for $12 \mathrm{~h}$. Finally, the samples were calcined at $500^{\circ} \mathrm{C}$ for $5 \mathrm{~h}$ in air atmosphere to remove water and any residual precursors remaining from the coprecipitation step. After cooling, the solid residues were ground using a ceramic mortar and pestle until fine powders were obtained. The rate of heating and cooling was always maintained at $10^{\circ} \mathrm{C} / \mathrm{min}$.
2.3. Synthesis of $\mathrm{Au} / \mathrm{CeO}_{2}(\mathrm{Au} / \mathrm{C})$ and $\mathrm{Au} / \mathrm{CeO}_{2}-\mathrm{ZrO}_{2}$ $(\mathrm{Au} / \mathrm{CZ})$. Gold was deposited over $\mathrm{CeO}_{2}$ and $\mathrm{CeO}_{2}-\mathrm{ZrO}_{2}$ to prepare $1 \mathrm{wt} \%$ of $\mathrm{Au}$ to the total amount of supports by employing a modified deposition-precipitation technique with urea (DPU). Typically, certain weighed amount of the support systems was dispersed in double distilled water under stirring condition and the temperature of the resulting suspension was increased up to $80^{\circ} \mathrm{C}$. Then a solution of $\mathrm{HAuCl}_{4} \cdot 3 \mathrm{H}_{2} \mathrm{O}$ (Himedia) was added slowly followed by the addition of urea. The concentration of $\mathrm{HAuCl}_{4} \cdot 3 \mathrm{H}_{2} \mathrm{O}$ solution was corresponding to $1 \mathrm{wt} \%$ of $\mathrm{Au}$ and the concentration ratio of urea to total metal was maintained at 100 . The resulting mixture was left for stirring for another 12 hours, covered by opaque aluminum foil to get rid of uncontrolled photoreduction. It was then centrifuged to gather the solid product and washed with distilled water until it became free from anion impurities. The collected solid was oven-dried at $120^{\circ} \mathrm{C}$ overnight, and finally it was calcined at $400^{\circ} \mathrm{C}$ for 12 hours.

2.4. Characterization of Catalysts. The BET surface areas were determined by $\mathrm{N}_{2}$ physisorption at liquid $\mathrm{N}_{2}$ temperature on a Micromeritics Gemini 2360 instrument. The powder X-ray diffraction (XRD) patterns were recorded on a Rigaku Multiflex instrument using nickel-filtered $\mathrm{CuK} \alpha$ $(0.15418 \mathrm{~nm})$ radiation source and a scintillation counter detector. The intensity data were collected over a $2 \theta$ range of $10-80^{\circ}$. The Raman spectra were collected on a DILORXY spectrometer equipped with a liquid-nitrogen-cooled CCD detector. Samples were excited with the emission line at $514 \mathrm{~nm}$ from an $\mathrm{Ar}^{+}$ion laser. UV-Vis diffuse reflectance spectra were recorded on a UV-visible spectrophotometer, Model U-4100 spectrophotometer (solid). Infrared spectra were taken in a FTIR spectrophotometer, Model Spectrum Two FT-IR Spectrometer (Perkin Elmer), by pelletizing the samples with $\mathrm{KBr}$ in the midinfrared region at an accelerating voltage of $200 \mathrm{~V}$. Transmission electron microscopic (TEM) investigations were made on a JEM-2100 (JEOL) instrument equipped with a slow scan CCD camera. XPS studies were carried out on a V-G Microtech unit ESCA 3000 Spectrometer with two anodes, $\mathrm{AlK} \alpha(1486.6 \mathrm{eV})$ and $\mathrm{MgK} \alpha(1256.6 \mathrm{eV})$. Prior to analysis, the samples were dried and evacuated at high vacuum and then introduced into the analysis chamber. The recorded XPS spectra were charge corrected with respect to the $\mathrm{C} 1 \mathrm{~s}$ peak at $284.6 \mathrm{eV}$. Inductively Coupled PlasmaAtomic Emission Spectroscopy (ICP-AES) measurements were carried out (model: ARCOS M/s. Spectro, Germany) in order to estimate the amount of Au deposited on the support.

2.5. Catalytic Activity Measurements. The catalytic activity of the synthesized catalysts was evaluated for the oxidation of $\mathrm{CO}$ at normal atmospheric pressure and temperatures in a fixed bed microreactor at a heating ramp of $5^{\circ} \mathrm{C} / \mathrm{min}$. About $80 \mathrm{mg}$ catalyst sample (250-355 $\mu \mathrm{m}$ sieve fraction) was placed in the reactor for evaluation. Temperature was measured directly at the catalyst bed, using a thermocouple placed in the hollow part of the reactor. The gases used (supplied by Assam Air Products) are helium ( $>99.9 \%$ purity), $10 \%$ CO in helium (CO purity, >99.9\%), and $10 \% \mathrm{O}_{2}$ in helium (oxygen 
TABLE 1: BET surface area, pore size, crystallite size, and lattice parameter of $\mathrm{C}, \mathrm{CZ}, \mathrm{Au} / \mathrm{C}$, and $\mathrm{Au} / \mathrm{CZ}$ samples.

\begin{tabular}{lcccc}
\hline Sample & $\begin{array}{c}\text { Surface area } \\
\left(\mathrm{m}^{2} \mathrm{~g}^{-1}\right)\end{array}$ & $\begin{array}{c}\text { Total pore } \\
\text { volume } \\
\left(\mathrm{m}^{2} \mathrm{~g}^{-1}\right)\end{array}$ & $\begin{array}{c}\text { Crystallite } \\
\text { size }(\mathrm{nm})\end{array}$ & $\begin{array}{c}\text { Lattice } \\
\text { parameter } \\
(\AA)\end{array}$ \\
\hline $\mathrm{C}$ & 72 & 0.0365 & 5.2 & 5.40 \\
$\mathrm{CZ}$ & 99 & 0.0499 & 4.8 & 5.35 \\
$\mathrm{Au} / \mathrm{C}$ & 61 & 0.0308 & $5.6^{\mathrm{a}}$ & 5.39 \\
$\mathrm{Au} / \mathrm{CZ}$ & 84 & 0.0417 & $5.0^{\mathrm{b}}$ & 5.36 \\
\hline
\end{tabular}

${ }_{\mathrm{a}, \mathrm{b}}$ For $\mathrm{C}$ and $\mathrm{CZ}$.

purity, $>99.9 \%)$. The total flow rates maintained by the mass flow controllers and flow meters were in the range of $40-$ $50 \mathrm{NmL} / \mathrm{min}$ (milliliters normalized to $273.15 \mathrm{~K}$ and $1 \mathrm{~atm}$.). Prior to oxidation of $\mathrm{CO}$, the catalysts were heated to $200^{\circ} \mathrm{C}$ in $10 \% \mathrm{O}_{2} / \mathrm{He}$ gas mixture, using a heating ramp of $10^{\circ} \mathrm{C} / \mathrm{min}$, and kept at the final temperature for $1 \mathrm{~h}$. The oxidized sample was then purged in helium and cooled to the desired starting temperature. The partial pressures of $\mathrm{CO}$ and $\mathrm{O}_{2}$ were in the range of 10 mbar. The conversion of $\mathrm{CO}$ was observed with the help of Gas Chromatograph (Perkin Elmer, model: Clarus 500) equipped with TCD detector.

\section{Results and Discussions}

The $\mathrm{N}_{2}$ BET surface areas of various samples are presented in Table 1 . The $\mathrm{C}$ and $\mathrm{CZ}$ samples calcined at $500^{\circ} \mathrm{C}$ bear rather high BET surface areas of 72 and $99 \mathrm{~m}^{2} \mathrm{~g}^{-1}$, respectively. Not surprisingly, the mixed oxide bears higher surface area than the pristine oxide. A gradual fall in surface area was noted when gold was deposited over those supports. This could be due to penetration of the Au-NPs into the pores of the support, thereby narrowing its pore diameter and blocking some of the micropores.

A systematic XRD study was performed to understand the phase symmetry and structure of the prepared samples. The powder XRD patterns of the $\mathrm{C}, \mathrm{CZ}, \mathrm{Au} / \mathrm{C}$, and $\mathrm{Au} / \mathrm{CZ}$ samples are presented in Figure 1.

All the patterns consist of prominent $\mathrm{CeO}_{2}$ crystal phases. The characteristic peaks were observed at $2 \theta=28.6^{\circ}, 32.9^{\circ}$, $47.5^{\circ}, 56.7^{\circ}, 59.3^{\circ}, 69.5^{\circ}$, and $76.7^{\circ}$ corresponding to the (111), (200), (220), (311), (222), (400), and (331) diffraction planes, respectively. It reveals the formation of face-centered cubic (fcc) fluorite type phase of $\mathrm{CeO}_{2}$. In the synthesized samples, no prominent peak for any other phase was found demonstrating the high purity of the synthesized product which in turn is in accordance with the literature $[19,20]$. Literature shows that, on doping metallic cation with radius smaller than $\mathrm{Ce}^{4+}$, the peak positions are slightly shifted towards the higher diffraction angles $(2 \theta)$ [21]. In this case, dopant cation $\mathrm{Zr}^{4+}$ bears ionic radius of $0.084 \mathrm{~nm}$, whereas that of $\mathrm{Ce}^{4+}$ is $0.097 \mathrm{~nm}$. Therefore, the observed shift in $2 \theta$ positions is the outcome of successful substitution of $\mathrm{Ce}^{4+}$ ions with isovalent $\mathrm{Zr}^{4+}$. This also confirms the formation of $\mathrm{CZ}$ solid solutions $[22,23]$. This incident is quite reinforced by the fact that $\mathrm{CZ}$ has smaller crystallite size than pure $\mathrm{CeO}_{2}$ (obtained

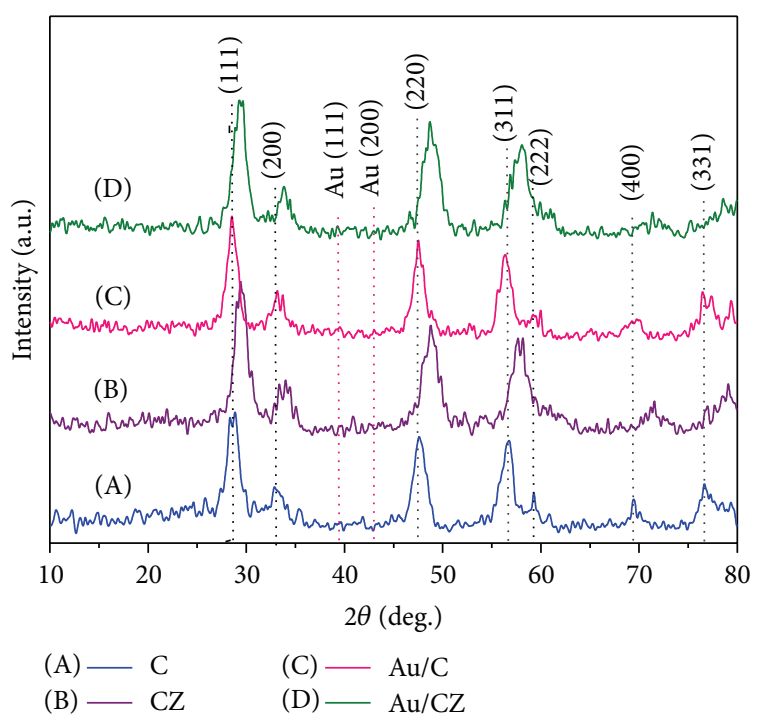

FIgure 1: Powder X-ray diffraction patterns of (A) $\mathrm{CeO}_{2}$ (C) and (B) $\mathrm{CeO}_{2}-\mathrm{ZrO}_{2}(\mathrm{CZ})$ samples calcined at $500^{\circ} \mathrm{C}$ and (C) $\mathrm{Au} / \mathrm{CeO}_{2}$ $(\mathrm{Au} / \mathrm{C})$ and $(\mathrm{D}) \mathrm{Au} / \mathrm{CeO}_{2}-\mathrm{ZrO}_{2}(\mathrm{Au} / \mathrm{CZ})$ samples calcined at $400^{\circ} \mathrm{C}$.

from Scherrer equation) as can be seen from the values given in Table $1[7,24]$. The broad nature of the peaks distinctly indicated the nanocrystalline nature of the samples in general. In the case of the $\mathrm{CZ}$ sample, broad diffraction lines pertaining to cubic fluorite type phases with the composition $\mathrm{Ce}_{0.6} \mathrm{Zr}_{0.4} \mathrm{O}_{2}$ (PDF-ICDD38-1439) and $\mathrm{Ce}_{0.5} \mathrm{Zr}_{0.5} \mathrm{O}_{2}$ (PDFICDD38-1436) were identified. It was observed that the support systems (i.e., C and CZ) bear relatively smaller crystallite size than the final gold decorated catalysts (i.e., $\mathrm{Au} / \mathrm{C}$ and $\mathrm{Au} / \mathrm{CZ}$ ). This indicates the smaller surface area of the gold supported samples, which is in agreement with the results obtained from the $\mathrm{N}_{2}$ BET surface area analysis of the synthesized materials. It is evident from Figure 1 that, in addition to the diffraction peaks corresponding to bare $\mathrm{CeO}_{2}$, two more very weak peaks centered at $2 \theta=39.4^{\circ}$ and $43.1^{\circ}$ were also detected which may arise due to the (111) and (200) facets of $\mathrm{Au}[25,26]$. However due to relatively low gold loading (only $1 \mathrm{wt} \%)$ diffraction peaks for gold are not well distinct which is also in accordance with the previous literature reports [25, $26]$. The actual gold contents in the gold supported samples were found to be 0.923 and 0.721 , respectively, for $\mathrm{Au} / \mathrm{C}$ and $\mathrm{Au} / \mathrm{CZ}$ (in terms of $\%$ as determined by ICP-AES).

The Raman spectra of $\mathrm{C}, \mathrm{CZ}, \mathrm{Au} / \mathrm{C}$, and $\mathrm{Au} / \mathrm{CZ}$ samples are shown in Figure 2. As can be seen from the figure, for all samples, a common, sharp, distinct, and strong Raman band centered at around $460-470 \mathrm{~cm}^{-1}$ could be observed. This peak is due to the only Raman-active mode of the perfect cubic fluorite structure of ceria $[7,27,28]$. This is again ascribed to the symmetric breathing mode of the oxygen atoms surrounding $\mathrm{Ce}^{4+}$ cation $[27,28]$. Moreover, the $\mathrm{CZ}$ sample shows one weak band at $598 \mathrm{~cm}^{-1}$ due to nondegenerate longitudinal optical (LO) mode of ceria, which arises due to relaxation of symmetry rules [29]. In particular, this band is correlated with the presence of the oxygen vacancies $\left(\mathrm{O}_{\mathrm{v}}\right)$ and/or lattice defects $\left(\mathrm{MO}_{8}\right.$-type complex defects). The 


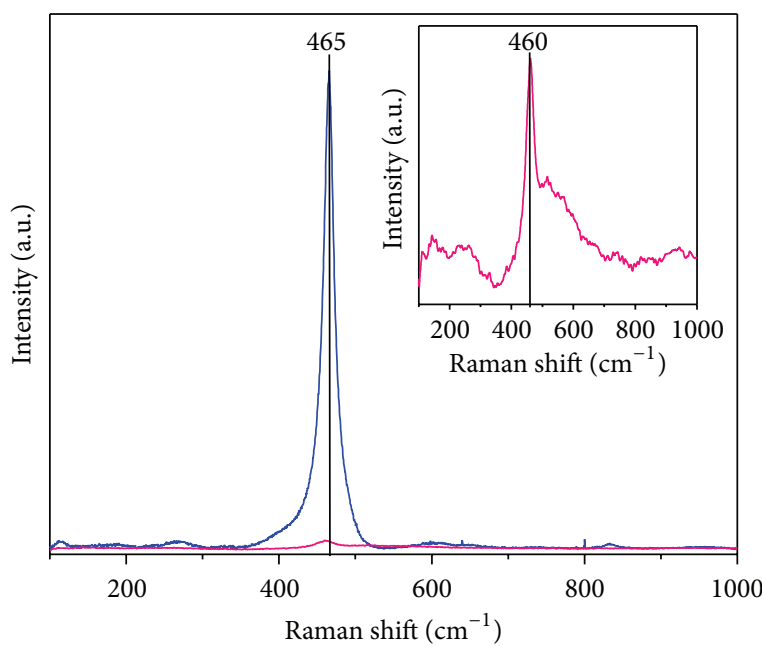

(A) $-\mathrm{C}$

(B) $-\mathrm{Au} / \mathrm{C}$

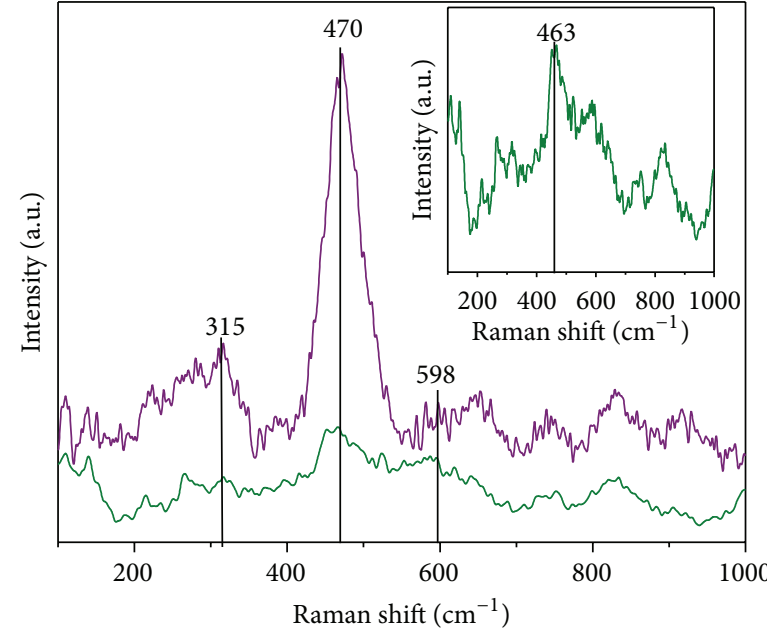

(C) $-\mathrm{CZ}$

(D)_ $\mathrm{Au} / \mathrm{CZ}$

(a)

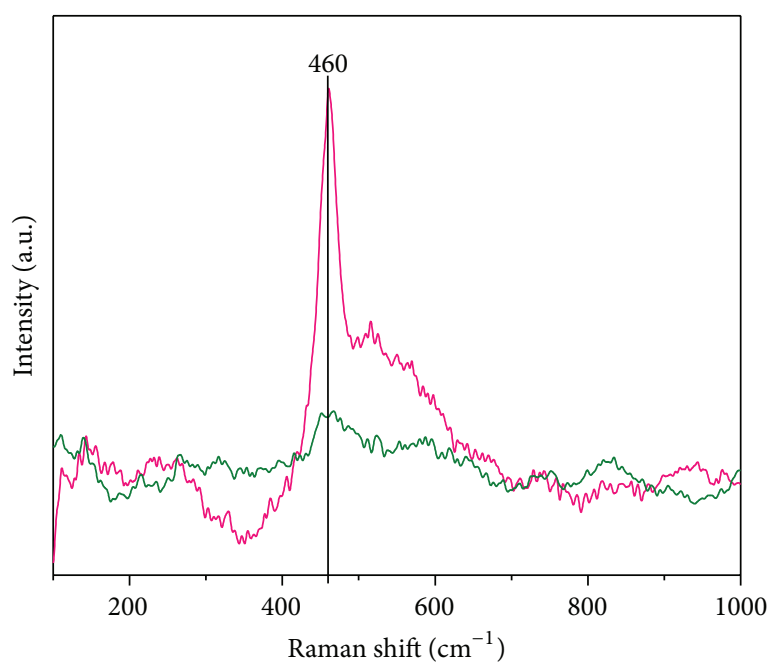

(B) $-\mathrm{Au} / \mathrm{C}$

(D) $-\mathrm{Au} / \mathrm{CZ}$

(c)

Figure 2: Raman spectra of (a) $\mathrm{CeO}_{2}(\mathrm{C})$ and $\mathrm{Au} / \mathrm{CeO}_{2}(\mathrm{Au} / \mathrm{C})$, (b) $\mathrm{CeO}_{2}-\mathrm{ZrO}_{2}(\mathrm{CZ})$ and $\mathrm{Au} / \mathrm{CeO}_{2}-\mathrm{ZrO}_{2}(\mathrm{Au} / \mathrm{CZ})$, and (c) $\mathrm{Au} / \mathrm{CeO}{ }_{2}(\mathrm{Au} / \mathrm{C})$ and $\mathrm{Au} / \mathrm{CeO}_{2}-\mathrm{ZrO}_{2}(\mathrm{Au} / \mathrm{CZ})$ samples.

defective structure is associated with relative amount of $\mathrm{Ce}^{3+}$ ions, preferentially placed on the surface of the sample that could be enhanced when dopant enters the lattice of cerium oxide [17, 30, 31]. It is evident from Figure 2(b) that incorporation of $\mathrm{Zr}^{4+}$ cation into the cubic fluorite lattice of ceria results in broadening of $\mathrm{F}_{2 \mathrm{~g}}$ band and is blue shifted towards higher wave numbers. This phenomenon indicates the formation of $\mathrm{CZ}$ mixed oxide and the broadness of the spectrum could be due to the presence of smaller crystallite size of ceria which is also established from XRD and BET surface area investigations [32]. In addition, the weak band at around $315 \mathrm{~cm}^{-1}$ represents the displacement of oxygen atoms from their ideal fluorite lattice positions, which shows that CZ sample contains more number of oxygen vacancies $[29,32]$. Interestingly, no Raman lines due to $\mathrm{ZrO}_{2}$ could be observed in line with XRD measurements. In the case of the gold supported samples, $\mathrm{F}_{2 \mathrm{~g}}$ band has been shifted to a slightly lower wavenumber $\left(\sim 460 \mathrm{~cm}^{-1}\right.$ as shown in the inset of Figures 2(a) and 2(b)). This shifting of $F_{2 g}$ mode implies that the deposition of gold on $\mathrm{CeO}_{2}$ lattice lowers the symmetry of the Ce-O bond $[28,33]$. The shift might indicate that the deposition of $\mathrm{Au}$ affects the support not only at the surface and it may be the result of the interaction with the chemicals involved, which in this case is urea. Moreover, it could be seen that $\mathrm{F}_{2 \mathrm{~g}}$ peak in unsupported $\mathrm{C}$ and $\mathrm{CZ}$ samples is relatively very much stronger than that in case of 


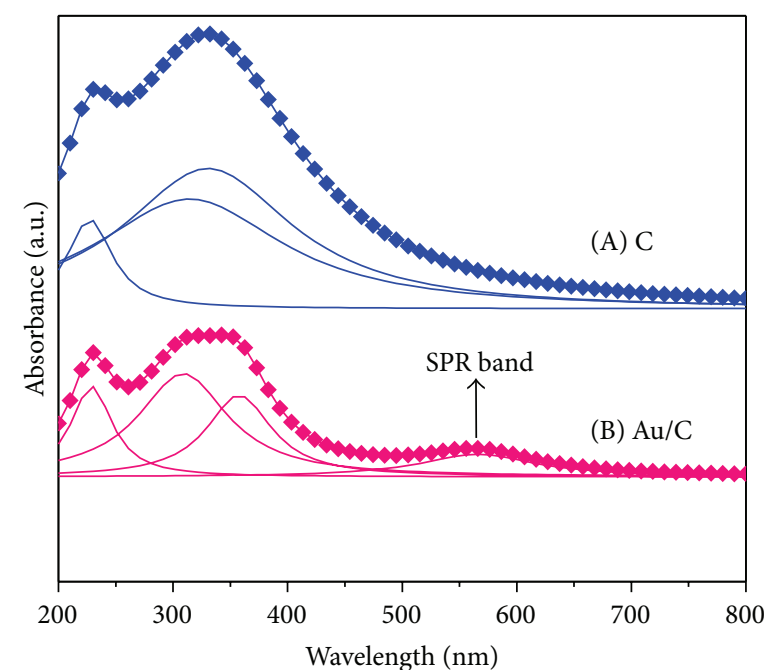

(a)

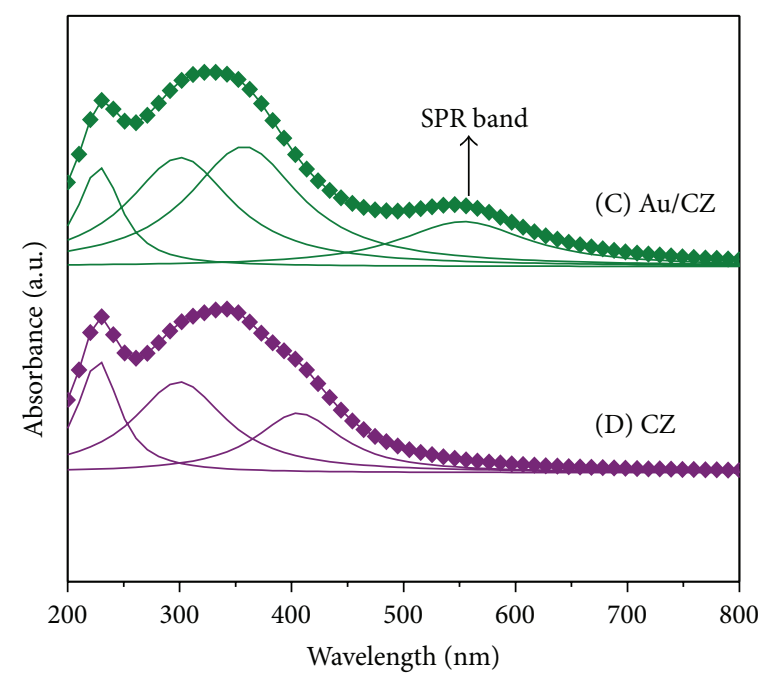

(b)

Figure 3: UV-Vis DRS patterns of (a) $\mathrm{CeO}_{2}(\mathrm{C})$ and $\mathrm{Au} / \mathrm{CeO}_{2}(\mathrm{Au} / \mathrm{C})$ and (b) $\mathrm{CeO}_{2}-\mathrm{ZrO}_{2}$ (CZ) and $\mathrm{Au} / \mathrm{CeO}_{2}-\mathrm{ZrO} 2(\mathrm{Au} / \mathrm{CZ})$ samples.

gold containing samples. As the CZ systems contain more oxygen vacancies or defect sites, it is rational to expect better catalytic efficiency of Au/CZ sample [19, 34].

The UV-Vis diffuse reflectance spectra for pristine ceria, doped ceria, and gold supported samples are shown in Figure 3. All the samples are found to be active in the UV region. Despite the difficulties to interpret the large bandwidth and specular reflectance usually observed in the DR spectra, this technique has extensive use to obtain information on surface coordination and different oxidation states of metal ions in ceria-based materials by measuring $d-$ $\mathrm{d}$ and $\mathrm{f}-\mathrm{d}$ transitions and oxygen-metal ion charge transfer bands [35]. It is known from the previous literature that $\mathrm{CeO}_{2}$ is fairly active in the near UV-Vis region due to its ntype semiconductivity nature [36]. UV absorption in $\mathrm{CeO}_{2}$ is illustrated by a charge transfer transition between $\mathrm{O} 2 \mathrm{p}$ and Ce 4f, not by an inner transition between Ce $4 \mathrm{f}$ and Ce $3 \mathrm{~d}$ bands [36]. As presented in Figure 3(a), the UV-Vis DR spectra of $\mathrm{CeO}_{2}$ exhibit three major absorption bands at about $\sim 227, \sim 312$, and $\sim 331 \mathrm{~nm}$. The absorption bands centered at $\sim 227 \mathrm{~nm}$ and $\sim 312 \mathrm{~nm}$ may be attributed to $\mathrm{O}^{2-} \rightarrow \mathrm{Ce}^{3+}$ and $\mathrm{O}^{2-} \rightarrow \mathrm{Ce}^{4+}$ charge transfer transitions, respectively, while the band at $\sim 331 \mathrm{~nm}$ may be likely to interband transition $[37,38]$. Incorporation of $\mathrm{Zr}^{4+}$ into the $\mathrm{CeO}_{2}$ lattice enables the material to absorb UV-Vis light relatively towards longer wavelength. It could be seen from Figure 3 that bare CZ sample shows absorption band at slightly higher wavelength with respect to pristine C. It is exposed that the light absorption efficacy of the Au-NPs varies with the nature of the supports, while the supports themselves exhibit little absorption of light with wavelengths longer than $400 \mathrm{~nm}$ [39]. Surface plasmon resonance $(\mathrm{SPR})$ is a fascinating characteristic shown by noble metal nanoparticles which is primarily dependent on the size, shape, and hence the oscillation of free electrons of the NPs [40]. As an example, nanorods have been known to show two plasmon resonances, one due to the transverse oscillation of the electrons around $520 \mathrm{~nm}$ for gold which is independent of aspect ratio and other due to longitudinal plasmon resonance increases with larger aspect ratios [41, 42]. It is obvious from Figure 3 that UV-Vis DR spectra of $\mathrm{Au} / \mathrm{C}$ and $\mathrm{Au} / \mathrm{CZ}$ samples show absorption bands at about 565 and $558 \mathrm{~nm}$, respectively, which are the distinctive SPR absorption exhibited by the supported Au-NPs. In this case, existence of surface plasmon resonance is an indication of Au-NPs deposited over the $\mathrm{C}$ and $\mathrm{CZ}$ materials.

The FT-IR spectra of $\mathrm{Au} / \mathrm{C}$ and $\mathrm{Au} / \mathrm{CZ}$ samples are shown in Figure 4 . The spectra were measured in the range from $400 \mathrm{~cm}^{-1}$ to $4000 \mathrm{~cm}^{-1}$. The very small and broad absorption bands at $\sim 3855$ and $\sim 3370 \mathrm{~cm}^{-1}$ were assigned to the stretching vibration of $\mathrm{O}-\mathrm{H}$ functional group [18]. The peak at $\sim 2920 \mathrm{~cm}^{-1}$ may be attributed to the N-H stretching vibration of amine formed from the decomposition products of urea and the important peaks found at $\sim 2300$ and $\sim 1380 \mathrm{~cm}^{-1}$ are due to the absorption of atmospheric $\mathrm{CO}_{2}$ on the metallic cations $[43,44]$. Another small band observed at about $\sim 2850 \mathrm{~cm}^{-1}$ may be due to $\mathrm{C}-\mathrm{H}$ bonds of organic compounds [3]. The band at $\sim 1615 \mathrm{~cm}^{-1}$ corresponds to $\mathrm{O}-\mathrm{H}$ bending of molecularly physisorbed $\mathrm{H}_{2} \mathrm{O}$ [18]. The IR band appearing at $\sim 1250$ and $\sim 1550 \mathrm{~cm}^{-1}$ is assumed to be due to the nitrogen oxide species [45]. The absorption band at $\sim 1450$ and $\sim 1042 \mathrm{~cm}^{-1}$ could be ascribed to the presence of unwanted $\mathrm{NO}_{3}{ }^{-}$groups and other residues, respectively [18, 46]. The bands sited in the range of $800-840$ and $\sim 520 \mathrm{~cm}^{-1}$ may be due to $\mathrm{Ce}-\mathrm{O}$ stretching frequency indicating the formation of ceria [47]. In addition to the peaks assigned above for both samples, the peak observed at $550 \mathrm{~cm}^{-1}$ could be recommended to $\mathrm{Zr}-\mathrm{O}$ bond for the Au/CZ sample [48].

The HRTEM images of bare ceria, doped ceria, and supported Au-NPs are presented in Figure 5. The morphology and structure of the Au-NPs were resoluted from HRTEM micrographs. The formation of Au-NPs was identified and differentiated by the lattice spacing measurements. It could 


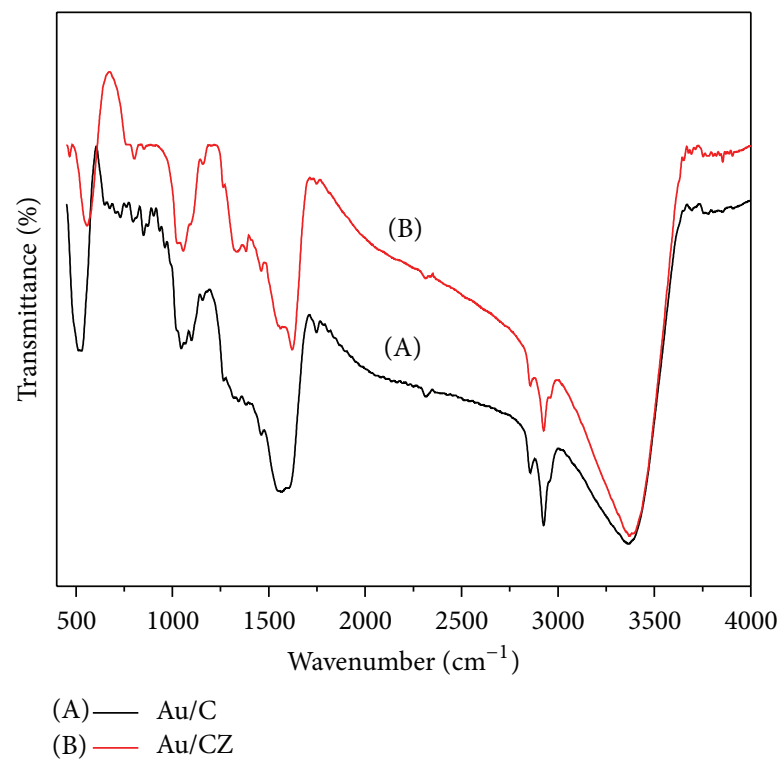

Figure 4: FTIR spectra of the as synthesized (A) $\mathrm{Au} / \mathrm{CeO}_{2}(\mathrm{Au} / \mathrm{C})$ and $(\mathrm{B}) \mathrm{Au} / \mathrm{CeO}_{2}-\mathrm{ZrO}_{2}(\mathrm{Au} / \mathrm{CZ})$ samples.

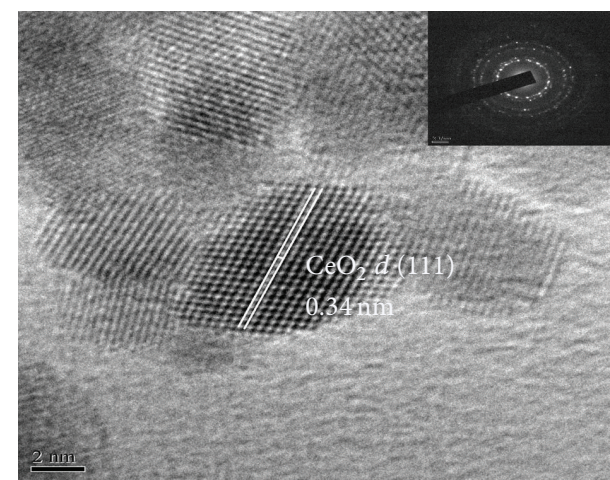

(a)

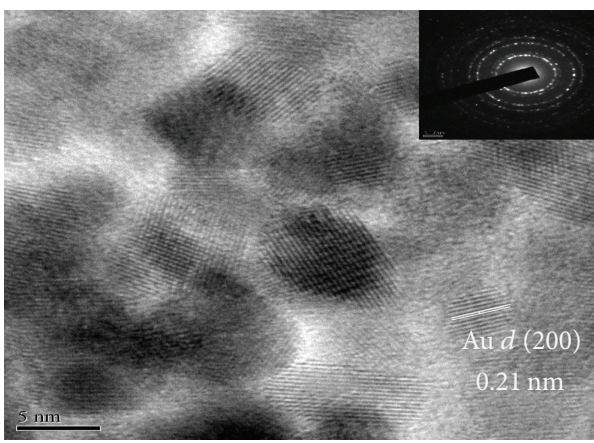

(c)

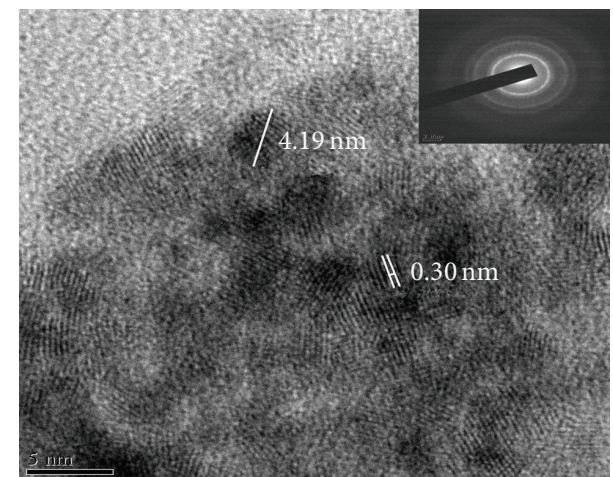

(b)

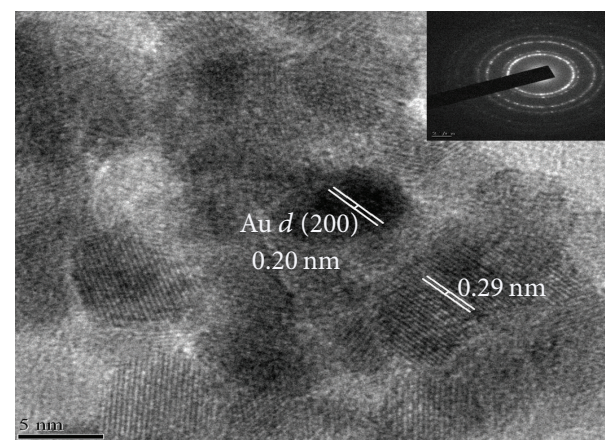

(d)

Figure 5: HRTEM images along with the respective SAED patterns of (a) $\mathrm{CeO}_{2}$ (C; scale bar: $2 \mathrm{~nm}$ ), (b) $\mathrm{CeO}_{2}-\mathrm{ZrO}_{2}(\mathrm{CZ}$; scale bar: $5 \mathrm{~nm}$ ), (c) $\mathrm{Au} / \mathrm{CeO}_{2}(\mathrm{Au} / \mathrm{C}$; scale bar: $5 \mathrm{~nm})$, and (d) $\mathrm{Au} / \mathrm{CeO}_{2}-\mathrm{ZrO}_{2}(\mathrm{Au} / \mathrm{CZ}$; scale bar: $5 \mathrm{~nm})$ samples.

be seen that Au-NPs are well dispersed over the $\mathrm{C}$ and $\mathrm{CZ}$ supports and have narrow but almost uniform size distributions and the particles are nearly spherical in shape with crystalline nature as revealed from the SAED patterns. The HRTEM images of supported Au-NPs as exposed in
Figures 5(c) and 5(d) focused on the presence of respective planes with lattice spacing of $0.21 \mathrm{~nm}$ in $\mathrm{Au} / \mathrm{C}$ and $0.20 \mathrm{~nm}$ in $\mathrm{Au} / \mathrm{CZ}$ due to the (200) plane of $\mathrm{Au}$ and this is well acquainted with the results obtained in XRD data [49]. The average particle size of the Au-NPs supported over C 


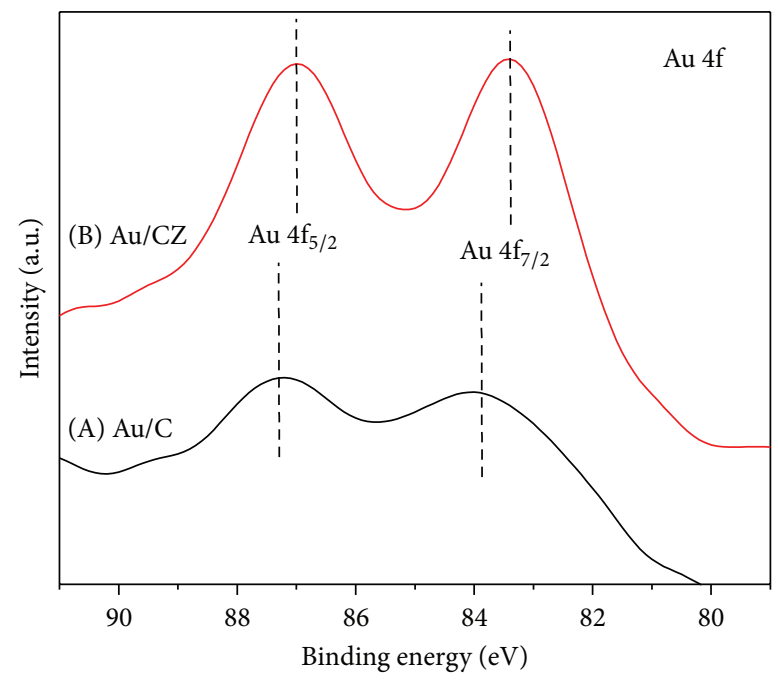

Figure 6: $\mathrm{Au}$ 4f XP spectra of (A) $\mathrm{Au} / \mathrm{CeO}_{2}(\mathrm{Au} / \mathrm{C})$ and $(\mathrm{B})$ $\mathrm{Au} / \mathrm{CeO}_{2}-\mathrm{ZrO}_{2}(\mathrm{Au} / \mathrm{CZ})$ samples.

and $\mathrm{CZ}$ is estimated to be in the range of 4 to $5 \mathrm{~nm}$ and the size of $C$ and $C Z$ samples is approximately 5 to $6 \mathrm{~nm}$ with fluorite cubic structure. These results are also in line with the crystallite sizes calculated by Scherrer equation from the XRD analysis. Furthermore, the corresponding selected area electron diffraction (SAED) patterns (shown as insets in Figure 5) clearly indicate the well crystallinity of the synthesized samples. According to previous literature, the cubic fluorite structure by and large exhibits only three electron diffraction rings which correspond to the interplanar spacings of ca. 3.1 (111), 2.7 (200), and $1.9(220) \AA[50,51]$. This feature is quite prominent in the prepared materials which are once again in compliance with the formation of cubic fluorite pattern of the materials.

XPS study was carried out in order to know the valence states of the elements contained in the synthesized catalysts. The XP spectra of Au $4 \mathrm{f}$ show a doublet corresponding to $\mathrm{Au}$ $4 \mathrm{f}_{7 / 2}$ and $\mathrm{Au} 4 \mathrm{f}_{5 / 2}$ states with a separation of $\sim 3.52 \mathrm{eV}$ [52]. As could be observed from Figure 6, binding energies of $\mathrm{Au}$ $4 \mathrm{f}_{7 / 2}$ state are $\sim 83.8 \mathrm{eV}$ and $\sim 83.4 \mathrm{eV}$, respectively, in $\mathrm{Au} / \mathrm{C}$ and $\mathrm{Au} / \mathrm{CZ}$ catalysts. The observed difference is plausibly due to the size effect. Similarly, $\mathrm{Au} 4 \mathrm{f}_{5 / 2}$ binding energies in $\mathrm{Au} / \mathrm{C}$ and $\mathrm{Au} / \mathrm{CZ}$ catalysts, respectively, are observed at $\sim 87.3 \mathrm{eV}$ and $\sim 87.02 \mathrm{eV}$. The corresponding binding energy values of both $\mathrm{Au} 4 \mathrm{f}$ states clearly confirm the presence of metallic gold $\left(\mathrm{Au}^{0}\right)$ species. However, literature shows that Au species may present as either metallic gold $\left(\mathrm{Au}^{0}\right)$ or cationic gold $\left(\mathrm{Au}^{+}\right.$ $4 \mathrm{f}_{7 / 2}$ at $84.5 \mathrm{eV}$ and $\mathrm{Au}^{3+} 4 \mathrm{f}_{7 / 2}$ at $\left.86.6 \mathrm{eV}\right)$ species [52, 53]. Thus, it can be concluded that Au species residing in the asprepared gold supported catalysts are only metallic in nature.

As per the literature, $\mathrm{O} 1 \mathrm{~s}$ spectra of ceria-based materials show two binding energies corresponding to different types of oxygen ions [52]. As shown in Figure 7, the peak observed at relatively lower binding energy $(\sim 530.0 \mathrm{eV})$ region stands for $\mathrm{CeO}_{2}$ lattice oxygen. On the contrary, the very small and dull shoulder at $\sim 532 \mathrm{eV}$ implies the presence of adsorbed carbonates and hydroxyl groups [52].

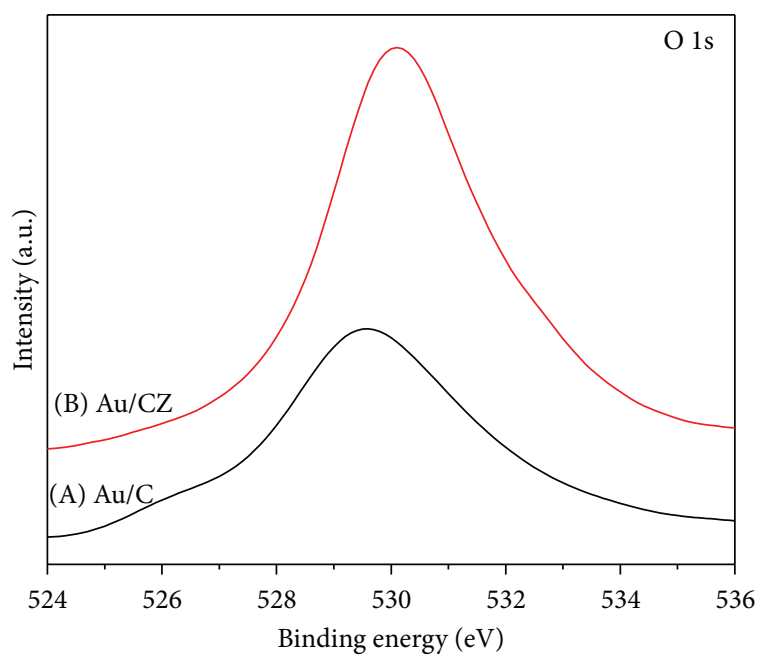

Figure 7: O 1s XP spectra of (A) $\mathrm{Au} / \mathrm{CeO}_{2}(\mathrm{Au} / \mathrm{C})$ and (B) $\mathrm{Au} / \mathrm{CeO}_{2}$ $\mathrm{ZrO}_{2}(\mathrm{Au} / \mathrm{CZ})$ samples.

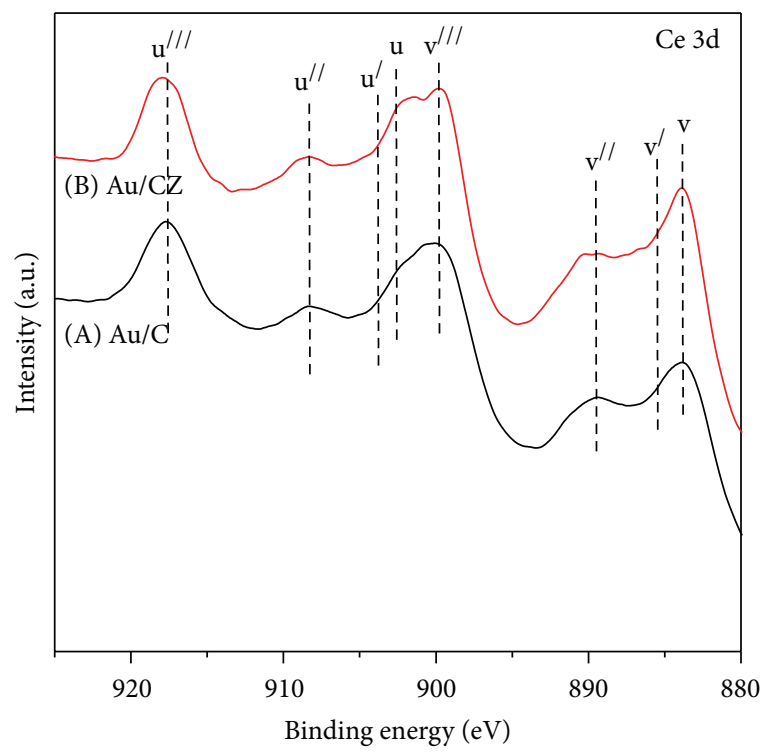

Figure 8: Ce 3d XP spectra of (A) $\mathrm{Au} / \mathrm{CeO}_{2}(\mathrm{Au} / \mathrm{C})$ and (B) $\mathrm{Au} / \mathrm{CeO}_{2}-\mathrm{ZrO}_{2}(\mathrm{Au} / \mathrm{CZ})$ samples.

Ce 3d XP spectra of the supported gold catalysts show two spin-orbit components, namely, $3 \mathrm{~d}_{3 / 2}$ and $3 \mathrm{~d}_{5 / 2}$, which have been represented by the notations $u$ and $v$, respectively, as shown in Figure 8. The corresponding peaks for $\mathrm{Ce}^{3+}$ state are symbolized by $\mathrm{u}^{\prime}(\sim 903.8 \mathrm{eV})$ and $\mathrm{v}^{\prime}(\sim 885.4 \mathrm{eV})$ and those for the $\mathrm{Ce}^{4+}$ state are represented by v $(\sim 883.8 \mathrm{eV}), \mathrm{u}$ ( $902.5 \mathrm{eV}), \mathrm{v}^{/ /}(\sim 889.4 \mathrm{eV}), \mathrm{u}^{\prime /}(908.2 \mathrm{eV}), \mathrm{v}^{\prime / I}(\sim 899.4 \mathrm{eV})$, and $\mathrm{u}^{/ / /}(\sim 917.6 \mathrm{eV})$. Accordingly, it was seen that Ce exists together as $\mathrm{Ce}^{3+}$ and $\mathrm{Ce}^{4+}$ ions in both synthesized gold supported catalysts [49].

The $\mathrm{Zr} 3 \mathrm{~d}$ XP spectrum of $\mathrm{Au} / \mathrm{CZ}$ catalyst is shown in Figure 9. Two peaks at $\sim 182.7$ and $184.6 \mathrm{eV}$ are observed in the spectrum. The lower binding energy peak is assigned to $\mathrm{Zr} 3 \mathrm{~d}_{5 / 2}$, whereas that at higher $\mathrm{BE}$ side is due to $\mathrm{Zr} 3 \mathrm{~d}_{3 / 2}$. The 


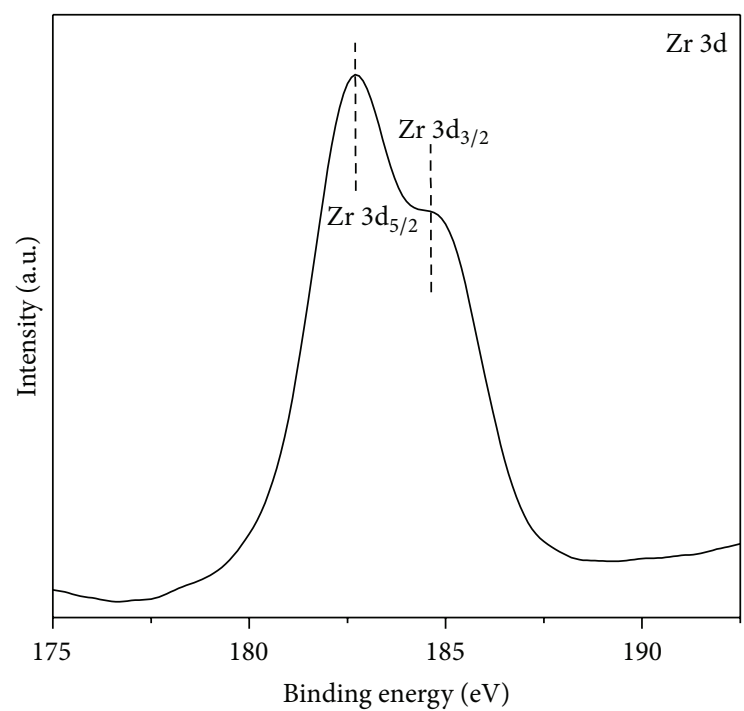

Figure 9: $\mathrm{Zr} 3 \mathrm{~d}$ XP spectra of $\mathrm{Au} / \mathrm{CeO}_{2}-\mathrm{ZrO}_{2}(\mathrm{Au} / \mathrm{CZ})$ sample.

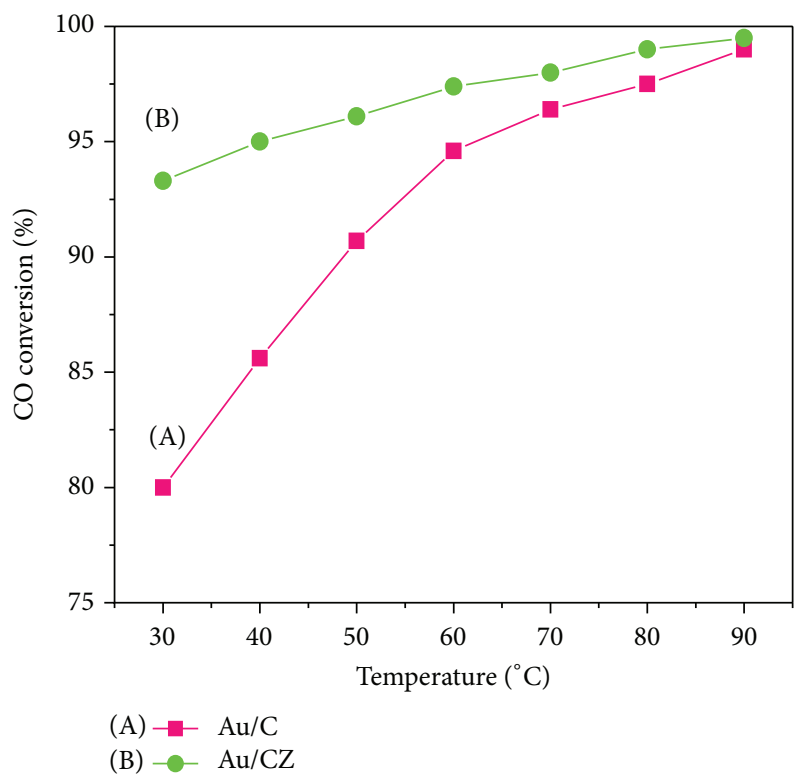

Figure 10: Conversion of $\mathrm{CO}$ versus temperature profiles of (A) $\mathrm{Au} / \mathrm{CeO}_{2}(\mathrm{Au} / \mathrm{C})$ and $(\mathrm{B}) \mathrm{Au} / \mathrm{CeO}_{2}-\mathrm{ZrO}_{2}(\mathrm{Au} / \mathrm{CZ})$ samples.

corresponding $\mathrm{BE}$ values for the two spin-orbit components in $\mathrm{Zr} 3 \mathrm{~d}$ spectra indicate the presence of $\mathrm{Zr}^{4+}$ ions [54].

The $\mathrm{CO}$ oxidation results of $\mathrm{Au} / \mathrm{C}$ and $\mathrm{Au} / \mathrm{CZ}$ samples as a function of reaction temperature are shown in Figure 10. It is well known that ceria and ceria-zirconia samples are very promising catalysts for $\mathrm{CO}$ oxidation at high temperatures (beyond $350^{\circ} \mathrm{C}$ ). In the present case, our prime emphasis was to explore the catalysts for low temperature activity. Therefore, the reaction temperature range we have chosen is from room temperature to $90^{\circ} \mathrm{C}$. Even at a lower temperature of $30^{\circ} \mathrm{C}$, both samples exhibited excellent activity for $\mathrm{CO}$ conversion. As observed from the figure, the $\mathrm{Au} / \mathrm{CZ}$ sample exhibited better $\mathrm{CO}$ conversion than $\mathrm{Au} / \mathrm{C}$. When $\mathrm{Au} / \mathrm{C}$ gave more than $80 \%$ CO conversion, $\mathrm{Au} / \mathrm{CZ}$ showed $\sim 100 \% \mathrm{CO}$ conversion at that temperature. There was a slight increase in $\mathrm{CO}$ conversion rate when temperature was raised and the samples exhibited full $\mathrm{CO}$ conversion at $90^{\circ} \mathrm{C}$. Interestingly, our synthesised catalysts have shown better catalytic activity than some recently reported results $[4,17,52]$. The observed more conversion by $\mathrm{Au} / \mathrm{CZ}$ sample could be due to increased oxygen mobility in the defective fluorite structure of $\mathrm{CZ}$ sample generated by introduction of more $\mathrm{Zr}^{4+}$ cations into the ceria core lattice compared to bare ceria. Thus, it could be assumed that the catalytic performance of Au catalysts is highly dependent on the nature of the support.

\section{Conclusions}

Nanosized ceria and ceria-zirconia solid solutions have been synthesized by a modified simple coprecipitation method and calcined at $500^{\circ} \mathrm{C}$. The Au supported samples were successfully synthesised using deposition-precipitation with urea method. A comparative study for CO oxidation activity has been undertaken with gold supported over ceria and ceria-zirconia. The results of XRD and cell parameter values revealed that zirconium is incorporated into the ceria lattice and more defective sites are formed. Raman spectroscopic measurements suggested the presence of oxygen vacancies, lattice defects, and displacement of oxygen ions from their ideal lattice positions. The surface plasmon band obtained from UV-Vis DRS analysis established the successful deposition of gold in the synthesized catalysts. The nanometer dimension of the prepared catalysts was confirmed from both XRD and TEM analysis. Better CO oxidation activity was observed for the $\mathrm{Au} / \mathrm{CZ}$ sample in comparison to that of $\mathrm{Au} / \mathrm{C}$ sample. In summary, it can be concluded that gold supported nanosized ceria and ceria-zirconia solid solutions by simple deposition-coprecipitation method using urea are an effective and promising approach for making catalysts for low temperature $\mathrm{CO}$ oxidation.

\section{Conflict of Interests}

The authors declare that there is no conflict of interests regarding the publication of this paper.

\section{Acknowledgments}

Pranjal Saikia and Abu Taleb Miah thank DST (New Delhi) for project Grant no. SR/FT/CS-69/2011. The authors also thank Shubhadeep Adak for helping in CO oxidation reaction.

\section{References}

[1] M. Haruta, T. Kobayashi, H. Sano, and N. Yamada, "Novel gold catalysts for the oxidation of carbon monoxide at a temperature far below $0^{\circ}$ C," Chemistry Letters, vol. 16, no. 2, pp. 405-408, 1987.

[2] M. Haruta, N. Yamada, T. Kobayashi, and S. Iijima, "Gold catalysts prepared by coprecipitation for low-temperature oxidation of hydrogen and of carbon monoxide," Journal of Catalysis, vol. 115, no. 2, pp. 301-309, 1989. 
[3] G. C. Bond, C. Louis, and D. T. Thompson, Catalysis by Gold, vol. 6 of Catalytic Science Series, Imperial College Press, London, UK, 2006.

[4] M. Haruta, S. Tsubota, T. Kobayashi, H. Kageyama, M. J. Genet, and B. Delmon, "Low-Temperature oxidation of CO over Gold supported on $\mathrm{TiO}_{2}, \alpha-\mathrm{Fe}_{2} \mathrm{O}_{3}$ and $\mathrm{Co}_{3} \mathrm{O}_{4}$," Journal of Catalysis, vol. 144, no. 1, pp. 175-192, 1993.

[5] A. Corma and H. Garcia, "Supported gold nanoparticles as catalysts for organic reactions," Chemical Society Reviews, vol. 37, no. 9, pp. 2096-2126, 2008.

[6] A. S. K. Hashmi, “The catalysis gold rush: new claims," Angewandte Chemie-International Edition, vol. 44, no. 43, pp. 6990-6993, 2005.

[7] B. M. Reddy, P. Bharali, P. Saikia et al., "Hafnium doped ceria nanocomposite oxide as a novel redox additive for three-way catalysts," The Journal of Physical Chemistry C, vol. 111, no. 5, pp. 1878-1881, 2007.

[8] M.-C. Daniel and D. Astruc, "Gold nanoparticles: assembly, supramolecular chemistry, quantum-size-related properties, and applications toward biology, catalysis, and nanotechnology ," Chemical Reviews, vol. 104, no. 1, pp. 293-346, 2004.

[9] P. Bharali, P. Saikia, and B. M. Reddy, "Large-scale synthesis of ceria-based nano-oxides with high CO oxidation activity," Catalysis Science \& Technology, vol. 2, no. 5, pp. 931-933, 2012.

[10] S. Scirè and L. F. Liotta, "Supported gold catalysts for the total oxidation of volatile organic compounds," Applied Catalysis B: Environmental, vol. 125, pp. 222-246, 2012.

[11] T. Barakat, J. C. Rooke, E. Genty, R. Cousin, S. Siffert, and B.-L. $\mathrm{Su}$, "Gold catalysts in environmental remediation and water-gas shift technologies," Energy \& Environmental Science, vol. 6, no. 2, pp. 371-391, 2013.

[12] C. D. Pina, E. Falletta, and M. Rossi, "Update on selective oxidation using gold," Chemical Society Reviews, vol. 41, no. 1, pp. 350-369, 2012.

[13] Y. Zhang, X. Cui, F. Shi, and Y. Deng, "Nano-gold catalysis in fine chemical synthesis," Chemical Reviews, vol. 112, no. 4, pp. 2467-2505, 2012.

[14] A. Cao, R. W. Lu, and G. Veser, "Stabilizing metal nanoparticles for heterogeneous catalysis," Physical Chemistry Chemical Physics, vol. 12, no. 41, pp. 13499-13510, 2010.

[15] Z. Ma and S. Dai, "Development of novel supported gold catalysts: a materials perspective," Nano Research, vol. 4, no. 1, pp. 3-32, 2011.

[16] X. Y. Liu, A. Wang, T. Zhang, and C.-Y. Mou, "Catalysis by gold: new insights into the support effect," Nano Today, vol. 8, no. 4, pp. 403-416, 2013.

[17] O. H. Laguna, F. R. Sarria, M. A. Centeno, and J. A. Odriozola, "Gold supported on metal-doped ceria catalysts $(\mathrm{M}=\mathrm{Zr}, \mathrm{Zn}$ and $\mathrm{Fe}$ ) for the preferential oxidation of CO (PROX)," Journal of Catalysis, vol. 276, no. 2, pp. 360-370, 2010.

[18] P. G. Babu, C. Kumar, K. Ravichandran, and P. Manohar, "Synthesis and characterization of zirconium tin titanate $\left(\mathrm{Zr}_{0.8} \mathrm{Sn}_{0.2} \mathrm{TiO}_{4}\right)$," International Journal of ChemTech Research, vol. 5, no. 5, pp. 2122-2129, 2013.

[19] B. M. Reddy, P. Bharali, G. Thrimurthulu, P. Saikia, L. Katta, and S.-E. Park, "Catalytic efficiency of ceria-zirconia and ceriahafnia nanocomposite oxides for soot oxidation," Catalysis Letters, vol. 123, no. 3-4, pp. 327-333, 2008.

[20] B. M. Reddy, P. Saikla, P. Bharali et al., "Structural characterization and catalytic activity of nanosized ceria-terbia solid solutions," The Journal of Physical Chemistry, vol. 112, no. 42, pp. 16393-16399, 2008.
[21] D. Devaiah, L. H. Reddy, K. Kuntaiah, and B. M. Reddy, "Design of novel ceria-based nano-oxides for CO oxidation and other catalytic applications," Indian Journal of Chemistry-Section A: Inorganic, Physical, Theoretical and Analytical Chemistry, vol. 51, no. 1-2, pp. 186-195, 2012.

[22] F. Zhang, C.-H. Chen, J. M. Raitano et al., "Phase stability in ceria-zirconia binary oxide nanoparticles: the effect of the $\mathrm{Ce}^{3+}$ concentration and the redox environment," Journal of Applied Physics, vol. 99, no. 8, Article ID 084313, 2006.

[23] P. Kumar, Y. Sun, and R. O. Idem, "Nickel-based ceria, zirconia, and ceria-zirconia catalytic systems for low-temperature carbon dioxide reforming of methane," Energy \& Fuels, vol. 21, no. 6, pp. 3113-3123, 2007.

[24] J. W. Niemantsverdriet, Spectroscopy in Catalysis, Wiley-VCH, New York, NY, USA, 1995.

[25] Q. Fu, S. Kudriavtseva, H. Saltsburg, and M. Flytzani-Stephanopoulos, "Gold-ceria catalysts for low-temperature water-gas shift reaction," Chemical Engineering Journal, vol. 93, no. 1, pp. 41-53, 2003.

[26] Q. Fu, A. Weber, and M. Flytzani-Stephanopoulos, "Nanostructured $\mathrm{Au}-\mathrm{CeO}_{2}$ catalysts for low-temperature water-gas shift," Catalysis Letters, vol. 77, no. 1-3, pp. 87-95, 2001.

[27] Q. Yuan, Q. Liu, W.-G. Song et al., "Ordered mesoporous $\mathrm{Ce}_{1-\mathrm{x}} \mathrm{Zr}_{\mathrm{x}} \mathrm{O}_{2}$ solid solutions with crystalline walls," Journal of the American Chemical Society, vol. 129, no. 21, pp. 6698-6699, 2007.

[28] X. Du, D. Zhang, L. Shi, R. Gao, and J. Zhang, "Morphology dependence of catalytic properties of $\mathrm{Ni} / \mathrm{CeO}_{2}$ nanostructures for carbon dioxide reforming of methane," The Journal of Physical Chemistry C, vol. 116, no. 18, pp. 10009-10016, 2012.

[29] B. M. Reddy and A. Khan, "Nanosized $\mathrm{CeO}_{2}-\mathrm{SiO}_{2}, \mathrm{CeO}_{2}-\mathrm{TiO}_{2}$, and $\mathrm{CeO}_{2}-\mathrm{ZrO}_{2}$ mixed oxides: Influence of supporting oxide on thermal stability and oxygen storage properties of ceria," Catalysis Surveys from Asia, vol. 9, no. 3, pp. 155-171, 2005.

[30] O. H. Laguna, M. A. Centeno, M. Boutonnet, and J. A. Odriozola, "Fe-doped ceria solids synthesized by the microemulsion method for CO oxidation reactions," Applied Catalysis B: Environmental, vol. 106, no. 3-4, pp. 621-629, 2011.

[31] A. Martínez-Arias, D. Gamarra, M. Fernández-García, X. Q. Wang, J. C. Hanson, and J. A. Rodriguez, "Comparative study on redox properties of nanosized $\mathrm{CeO}_{2}$ and $\mathrm{CuO} / \mathrm{CeO}_{2}$ under $\mathrm{CO} / \mathrm{O}_{2}$," Journal of Catalysis, vol. 240, no. 1, pp. 1-7, 2006.

[32] G. K. Reddy, G. Thrimurthulu, and B. M. Reddy, "A rapid microwave-induced solution combustion synthesis of ceriabased mixed oxides for catalytic applications," Catalysis Surveys from Asia, vol. 13, no. 4, pp. 237-255, 2009.

[33] M. Fernández-García, A. Martínez-Arias, J. C. Hanson, and J. A. Rodriguez, "Nanostructured oxides in chemistry: characterization and properties," Chemical Reviews, vol. 104, no. 9, pp. 4063-4104, 2004.

[34] H. Fujimori, M. Yashima, S. Sasaki et al., "Internal distortion in ceria-doped hafnia solid solutions: high-resolution $\mathrm{x}$-ray diffraction and Raman scattering," Physical Review B, vol. 64, no. 13, Article ID 134104, 2001.

[35] B. M. Weckhuysen and R. A. Schoonheydt, "Recent progress in diffuse reflectance spectroscopy of supported metal oxide catalysts," Catalysis Today, vol. 49, no. 4, pp. 441-451, 1999.

[36] S. Tsunekawa, T. Fukuda, and A. Kasuya, "Blue shift in ultraviolet absorption spectra of monodisperse $\mathrm{CeO}_{2-x}$ nanoparticles," Journal of Applied Physics, vol. 87, no. 3, pp. 1318-1321, 2000.

[37] D. Devaiah, D. Jampaiah, P. Saikia, and B. M. Reddy, "Structure dependent catalytic activity of $\mathrm{Ce}_{0.8} \mathrm{~Tb}_{0.2} \mathrm{O}_{2-\delta}$ and $\mathrm{TiO}_{2}$ supported $\mathrm{Ce}_{0.8} \mathrm{~Tb}_{0.2} \mathrm{O}_{2-\delta}$ solid solutions for CO oxidation," Journal 
of Industrial and Engineering Chemistry, vol. 20, no. 2, pp. 444453, 2014.

[38] B. M. Reddy, G. Thrimurthulu, L. Katta, Y. Yamada, and S.E. Park, "Structural characteristics and catalytic activity of nanocrystalline ceria-praseodymia solid solutions," The Journal of Physical Chemistry C, vol. 113, no. 36, pp. 15882-15890, 2009.

[39] X. Ke, X. Zhang, J. Zhao, S. Sarina, J. Barry, and H. Zhu, "Selective reductions using visible light photocatalysts of supported gold nanoparticles," Green Chemistry, vol. 15, no. 1, pp. 236-244, 2013.

[40] S. Eustis and M. A. El-Sayed, "Why gold nanoparticles are more precious than pretty gold: noble metal surface plasmon resonance and its enhancement of the radiative and nonradiative properties of nanocrystals of different shapes," Chemical Society Reviews, vol. 35, no. 3, pp. 209-217, 2006.

[41] M. A. El-Sayed, "Some interesting properties of metals confined in time and nanometer space of different shapes," Accounts of Chemical Research, vol. 34, no. 4, pp. 257-264, 2001.

[42] B. O. Dabbousi, J. Rodriguez-Viejo, F. V. Mikulec et al., "(CdSe) $\mathrm{ZnS}$ core-shell quantum dots: synthesis and characterization of a size series of highly luminescent nanocrystallites," Journal of Physical Chemistry B, vol. 101, no. 46, pp. 9463-9475, 1997.

[43] P. Hauck, A. Jentys, and J. A. Lercher, "Surface chemistry and kinetics of the hydrolysis of isocyanic acid on anatase," Applied Catalysis B: Environmental, vol. 70, no. 1-4, pp. 91-99, 2007.

[44] S. Phoka, P. Laokul, E. Swatsitang, V. Promarak, S. Seraphin, and S. Maensiri, "Synthesis, structural and optical properties of $\mathrm{CeO}_{2}$ nanoparticles synthesized by a simple polyvinyl pyrrolidone (PVP) solution route," Materials Chemistry and Physics, vol. 115, no. 1, pp. 423-428, 2009.

[45] J. A. Navio, C. Cerrillos, and C. Real, "Photo-induced transformation, upon UV illumination in air, of hyponitrite species $\mathrm{N}_{2} \mathrm{O}_{2}^{2-}$ preadsorbed on TiO2 surface," Surface \& Interface Analysis, vol. 24, no. 5, pp. 355-359, 1996.

[46] M. Chelliah, J. B. B. Rayappan, and U. M. Krishnan, "Synthesis and characterization of cerium oxide nanoparticles by hydroxide mediated approach," Journal of Applied Sciences, vol. 12, no. 16, pp. 1734-1737, 2012.

[47] E. Kumar, P. Selvarajan, and D. Muthuraj, "Synthesis and characterization of $\mathrm{CeO}_{2}$ nanocrystals by solvothermal route," Materials Research, vol. 16, no. 2, pp. 269-276, 2013.

[48] I. M. Low and R. McPherson, "Crystallization of gel-derived alumina and alumina-zirconia ceramics," Journal of Materials Science, vol. 24, no. 3, pp. 892-898, 1989.

[49] B.-B. Chen, C. Shi, M. Crocker, Y. Wang, and A.-M. Zhu, "Catalytic removal of formaldehyde at room temperature over supported gold catalysts," Applied Catalysis B: Environmental, vol. 132-133, pp. 245-255, 2013.

[50] B. M. Reddy, P. Lakshmanan, A. Khan, C. López-Cartes, T. C. Rojas, and A. Fernández, "Structural characterization of $\mathrm{CeO}_{2}$ $\mathrm{ZrO}_{2} / \mathrm{TiO}_{2}$ and $\mathrm{V}_{2} \mathrm{O}_{5} / \mathrm{CeO} 2-\mathrm{ZrO}_{2} / \mathrm{TiO}_{2}$ mixed oxide catalysts by XRD, raman spectroscopy, HREM, and other techniques," Journal of Physical Chemistry B, vol. 109, no. 5, pp. 1781-1787, 2005.

[51] G. Colón, F. Valdivieso, M. Pijolat, R. T. Baker, J. J. Calvino, and S. Bernal, "Textural and phase stability of $\mathrm{Ce}_{x} \mathrm{Zr}_{1-x} \mathrm{O}_{2}$ mixed oxides under high temperature oxidising conditions," Catalysis Today, vol. 50, no. 2, pp. 271-284, 1999.

[52] P. Sudarsanam, B. Mallesham, P. S. Reddy, D. Großmann, W. Grünert, and B. M. Reddy, "Nano- $\mathrm{Au} / \mathrm{CeO}_{2}$ catalysts for $\mathrm{CO}$ oxidation: Influence of dopants ( $\mathrm{Fe}, \mathrm{La}$ and $\mathrm{Zr}$ ) on the physicochemical properties and catalytic activity," Applied Catalysis B: Environmental, vol. 144, pp. 900-908, 2014.

[53] C. Santra, S. Rahman, S. Bojja et al., "Barium, calcium and magnesium doped mesoporous ceria supported gold nanoparticle for benzyl alcohol oxidation using molecular $\mathrm{O}_{2}$," Catalysis Science \& Technology, vol. 3, no. 2, pp. 360-370, 2013.

[54] X. Zhang, H. Shi, and B.-Q. Xu, "Vital roles of hydroxyl groups and gold oxidation states in $\mathrm{Au} / \mathrm{ZrO}_{2}$ catalysts for 1,3-butadiene hydrogenation," Journal of Catalysis, vol. 279, no. 1, pp. 75-87, 2011. 

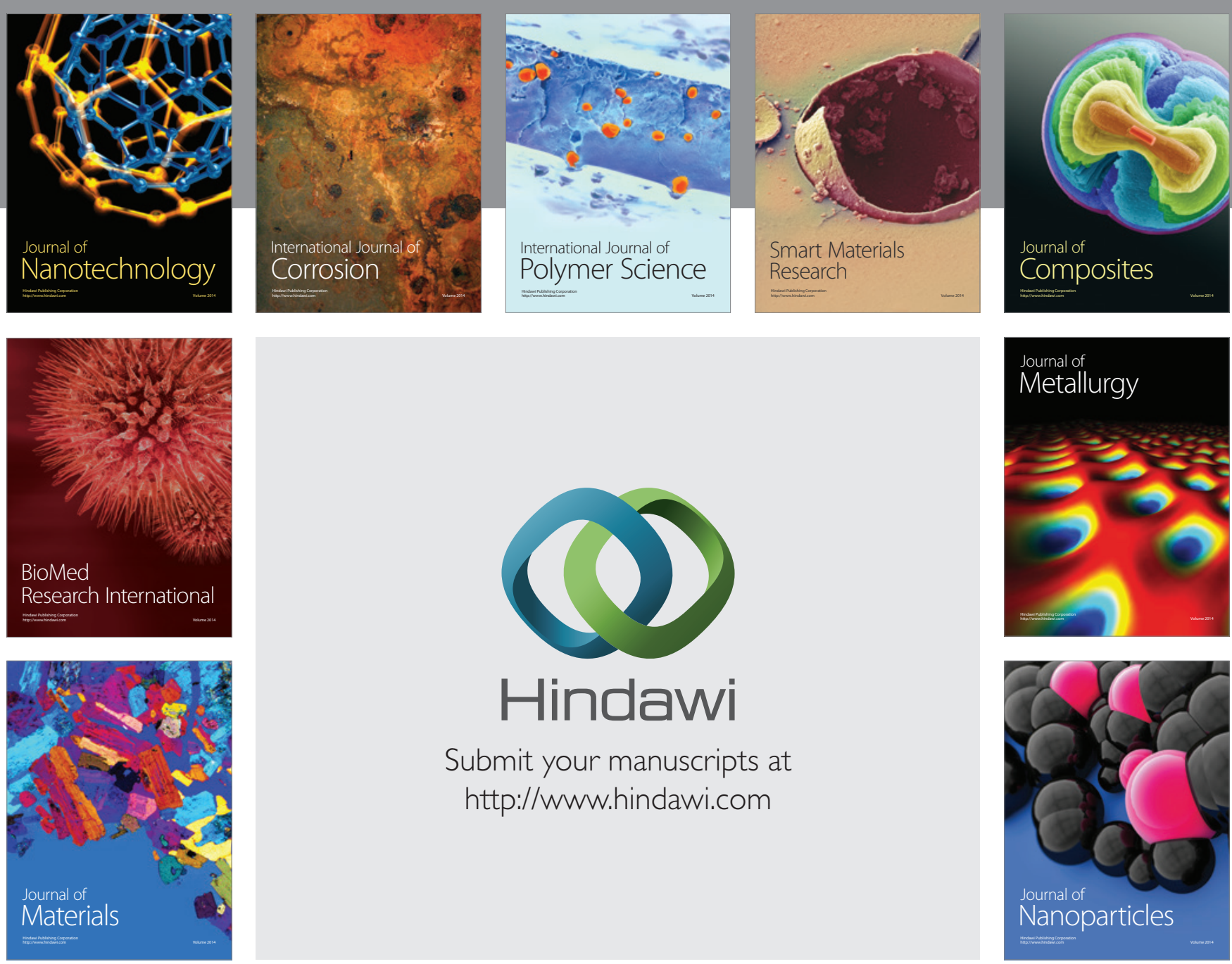

Submit your manuscripts at http://www.hindawi.com
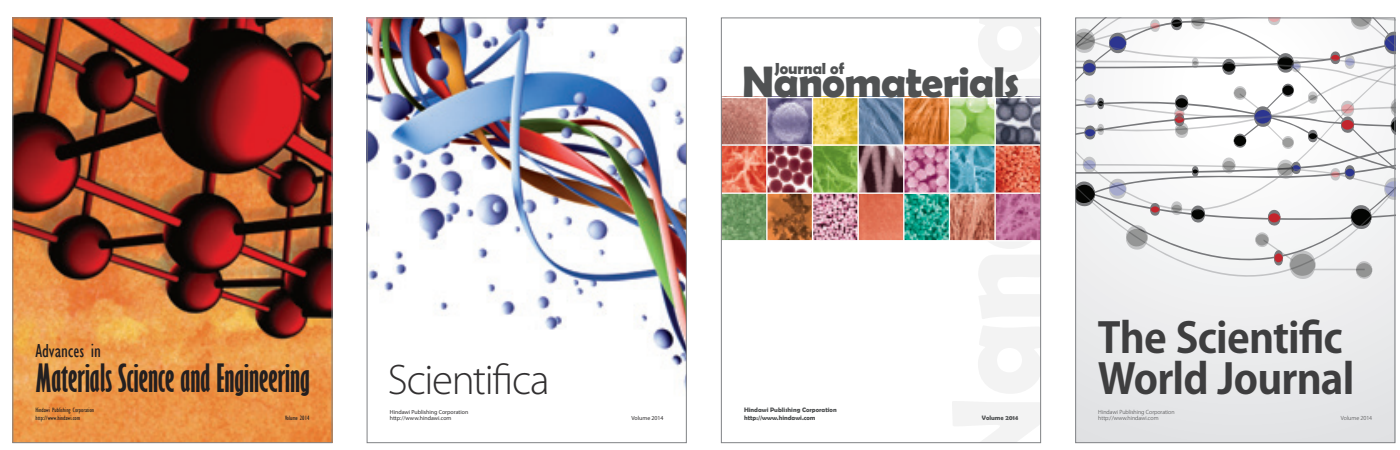

\section{The Scientific World Journal}
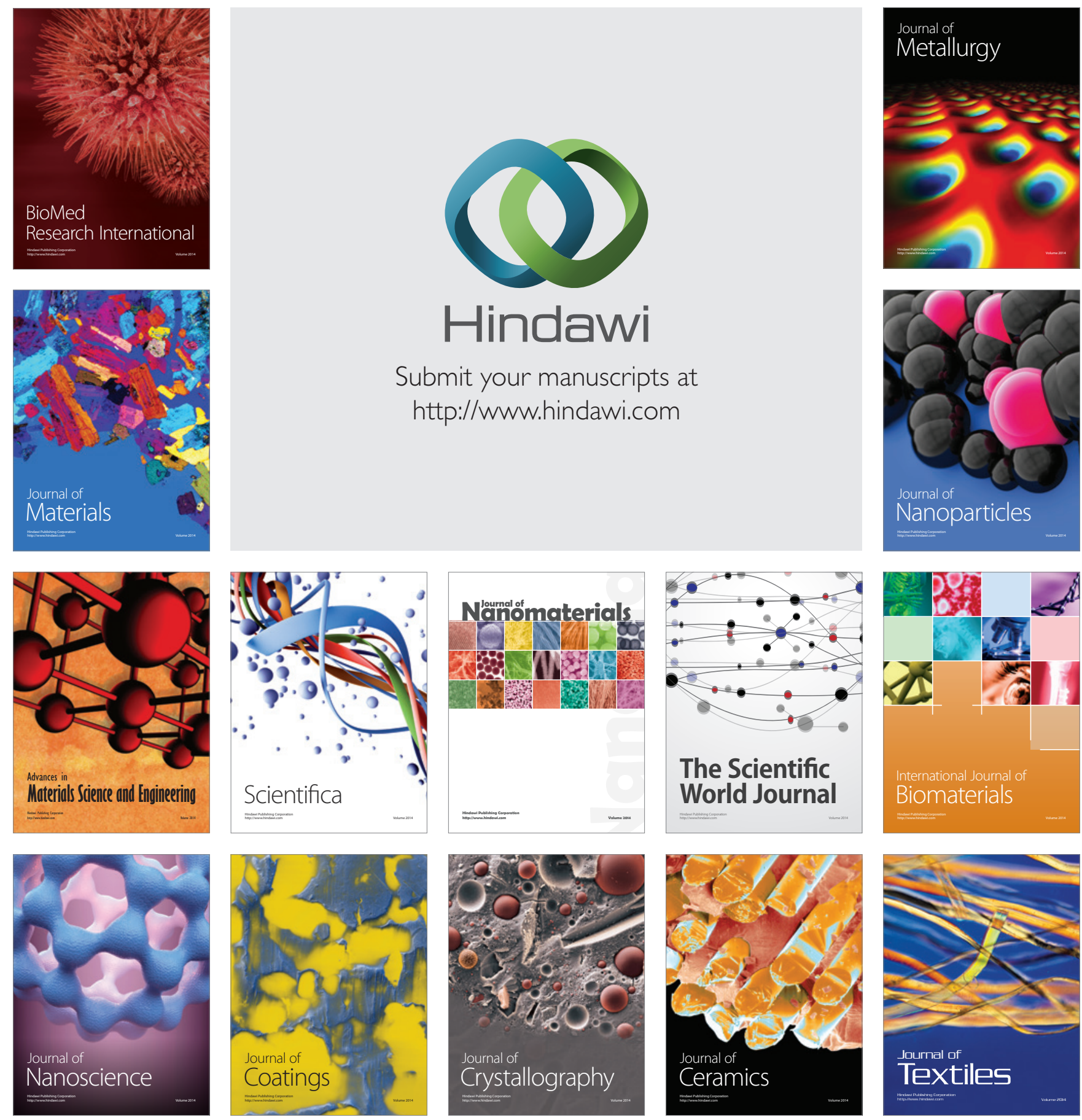